\title{
Cooperative Planning and Teaching (CPT)between Teachers and the Teacher Librarian in a Hong Kong Primary School to equip students with information literacy skill
}

\author{
Yuet Ha Angel Leung \\ Primary School Mistress Curriculum Development \\ G.C.E.P.S.A. Tseung Kwan O Primary School \\ Hong Kong Special Administrative Region, China
}

\begin{abstract}
In this information explosion era, information literacy skill becomes a survival skill. Creativity leads the way the world changes. Knowledge continues to be renewed and constructed. The role of education is to equip students with life long independent learning skill -- information literacy skill, which has to be obtained in curriculum context. Subject teachers alone or the teacher librarian alone cannot provide the necessary learning context. Cooperative Planning and Teaching (CPT) between them to integrate information literacy skill into the curriculum provides the necessary context. It has to be facilitated by flexible library scheduling. This paper presents the process of initiating CPT in a primary school in Hong Kong.
\end{abstract}

\section{The relationship between information literacy and education reform}

Change is natural. But, how does it affect education? Manufacturers of vehicles are clever not to produce too many parts of a particular vehicle model because it will soon be taken over by newer ones. A friend of mine went to study abroad for five years. When she returned to Hunan, her hometown in China, three nearby hills disappeared. Buildings have taken their places. Information technology keeps on renewing everyday. Creativity dominates and leads the change. Before, no one ever thought of providing information and entertainment on a bus trip. Now, we enjoy programs as well as being exposed to all sorts of information in "Road Show" during the short period of bus ride. People make a lot of money with the advertisements and programs in "Road Show" in Hong Kong. The rapid 
ever-changing world causes the paradigm shift of teachers and students. The speed of change is so fast that by the time teachers have memorized all they have learned and then pass onto students, it becomes outdated. Students cannot rely on and wait for teachers to pass on them knowledge which becomes outdated quickly. A very good example of this is the "nine planets". At present, there are no longer nine planets. Scientists claim that there should be only "eight planets" (Wikipedia, 2007). But all the printed materials still say "nine planets". The change speed is so fast that teachers and students have to acquire the necessary information technology skill at the same time. Given the fact that technology in the teachers' school days is less advanced, students often learn technology skill much faster than teachers do. The knowledge being updated is recorded as information in various media. So information literacy skill -- lifelong independent learning skill becomes a survival skill. Creativity leads the way the world is changing. Memorizing, copying and reproducing solely cannot meet today's information need. The role of education is to equip students with the skill to learn independently and to construct their own knowledge. The role of teachers is to facilitate such learning.

\section{Integrating information literacy skill into the curriculum}

\section{Rote learning develops memorizing skills only}

Traditionally, in primary school subjects, for example General Studies, teachers tell students what happen to the food we take. Where will they go? What will they change into? What is the final product? Then students memorize what is told and reproduce it during the assessments. Students with good memory can get high scores. They are the successful students in the class. They are praised and loved by teachers and parents. When they leave school, they can easily find a job in the society. Those who lack memorizing skill score low marks. They fail in assessments. They are blamed to be lazy and useless. They are not motivated to learn anymore. Research shows that students as young as primary three start to experience learning difficulty and failures. (Education Department, HKSAR, China, 1997, Chapter 7) Continuous failure discourages them to learn. According to the above assessment criteria, students with the potential, abilities and skills other than memorizing skills, are ignored by the schools and the society.

Nowadays, creativity leads the way the world is changing. Memorizing, copying and reproducing solely cannot meet today's information need.

Learning independently 
Knowledge cannot be passed from one to another. Knowledge has to be constructed. Learning needs a context. It won't happen in a vacuum. Students need to be challenged with a problem going to be solved. "Resource-based learning is a methodology that allows students to learn from their own confrontation with information resources." (Australian School Library Association \& Australian Library and Information Association, 1993, p.3)

If we ask students to find out the answers of the above questions from all sorts of information resources, they have to equip themselves with the necessary information skills. The more information literate they are the easier they can find out the answer. Students are then motivated to learn such skill. The roles of the teachers and the learning activities are also critical at this moment. Teachers can now train students the Big 6 skill (Eisenberg \& Berkowitz, 1987, p.11) to enable them to find the answers as follows:

1. Defining the problem to be solved - To find out what happens to the food we take. Where will they go? What will they change into? What is the final product?

2. Locating information - To access all the information resources available that answers the above questions.

3. Selecting information - Out of all the information accessed, select those that are particularly suitable for the learner to comprehend, rephrase, re-organize and present to his or her potential audience. Whether he wants models, pictures, diagrams, tables or just text to assist him in the presentation? Which are the main points he is focusing on? Is he going to answer the question in essay form, using realia or models, acting a play or by means of powerpoint slides?

4. Analyzing and organizing the information - summarize, rephrase, integrate, sequence and organize relevant information that answer the above questions in the order of the presentation.

5. Presenting - Role play, drama, display, report, powerpoint slides, web pages, etc can be used to present the answers.

6. Evaluating the above processes, reflecting on both success and failure based on the experience just gained to provide reference to further problems to be solved.

Learning can be transferred when they encounter similar situations.

Inquiry Learning, Problem Based Learning, Resource Based Learning, Project Learning and Liberal Study developed during the Hong Kong education reform are learning models to develop students' information literacy skills. All undergo the above 6 stages.

Information literacy skills, language skills and generic skills

When students are practicing the "Big 6 skill", they read various resources to locate, select, analyze and synthesize information to solve defined problems. Knowledge is 
constructed by the learners themselves. Apart from leisure reading, students are encouraged to read materials related to the curriculum. They are guided to read and exposed to all kinds of information resources, including online resources, which is similar to real life situation. Reading is anywhere at anytime when necessary. Reading is promoted quantitatively and qualitatively. In 2001, our school started implementing Cooperative Planning and Teaching to train students' information literacy skill. Every student read much more than usual. After one year, in 2002, we were awarded one of the 5 schools in Hong Kong which promoted the most reading.

Students write notes, reports and essays during the "Locating", "Analyzing" and "Presentation" stages. They communicate their learning product to the audience. Language skills of writing, speaking and listening are trained, too. Generic skills (The Curriculum Development Council, HKSAR, China, 2001, p.24) such as communicative, critical thinking, collaborative, creative, information technology, problem solving, numeric and self management skills are practiced, too.

\section{Who should be responsible for developing students' information literacy skill?}

Reading is one of the language skills, so language teachers should be responsible. But they have tight teaching schedules, which include writing, listening and speaking skills as well. They need the library collection to promote reading. They need the knowledge of the collection to search for resources that suit their students' learning topics, ability, learning style and interest during the "Big 6 skill" stages. How can they manage the collection and teach at the same time? They can't afford time and human resources to run the school library. This is why the Hong Kong Education Department started to offer a central library and a full time teacher librarian to every primary school since 1998. But teaching and learning haven't changed much since then. There is a huge gap between the budget spent on such resource and the awareness with regard to the role of the teacher librarians in schools. The guidelines from the Hong Kong Education Department on the duties of the teacher librarians don't articulate the unique and professional roles of a teacher librarian. They don't differentiate the roles of a teacher librarian and a non-teacher librarian. According to the guidelines, one of the duties is to carry out other suitable duties delegated by the principal. As a result, most principals regard the newly appointed teacher librarian as an extra teaching staff and assign him or her teaching jobs. Some principals assign a few teachers to take turns to be the teacher librarian to manage the library. They share the extra human resource across all the subjects in the school, ending up with some teachers getting more free lessons and spare time to accomplish other school duties. The timetable for library programs remains unchanged. Although there is a school library, teachers don't know its collection and services. They don't know when the library and the teacher librarian are available for his/her class of students. On the other hand, the newly appointed teacher librarians have not been trained professionally 
to play their roles. The principals and teachers can't see the contribution made by the teacher librarians. They query how the teacher librarian contributes to teaching and learning if he/she stays in the library without teaching any of the subjects. Library skills alone don't take too many lessons. To be fair to all staff, he/she has to take some of the teaching duties.

Inquiry Learning, Problem Based Learning, Resource Based Learning, Project Learning and Liberal Study are teaching approaches, which allow learners' direct confrontation with all sorts of learning resources. In the above approaches, students are guided to define their learning needs or the problem to be solved, locate and retrieve relevant information to solve the problem, select and analyze it, process it to present to the audience and evaluate the learning process. These approaches develop students' information literacy skills. Subject teachers alone or the teacher librarian alone cannot provide such training. Cooperative Planning and Teaching (CPT) between teachers and the teacher librarian to plan, teach and evaluate programs facilitates such training. "Lessons, activities, assignments on units of study will be planned co-operatively by the teacher and library staff by first checking to see the extent of relevant resources in the library." (Fischer, 2000, p.18) Only with a flexible library schedule can Cooperative Planning and Teaching be implemented.

\section{Flexible library scheduling}

In the existing library timetable, library skills taught by teacher librarians are isolated from all other subjects. Skills taught are not in subject context. Teacher librarians promote extra curricular reading and leisure reading only. They never know, or not in a position to know what other subject teachers of different levels are teaching. Reading in the library is thus confined to leisure activity, which is not taught as an information literacy skill.

"Resource-based learning facilitates a constructivist approach to learning; it facilitates student engagement and active learning. It also provides the appropriate classroom structures to facilitate free-flow to and from the library resource center; children are engaged in active work and the classroom tends not to be teacher-centered." (Carol-Ann Page, 1999, p.226)

An analysis of the existing library program of my school found that library skills taught in isolated library programs are repeated in academic subject areas. Some of them are outdated. "Library and other research and reading skills will no longer be isolated experiences but will be learnt in subject context." (Fischer, 2000, p.18) The Consultation Document on Review of Education System: Framework for Education Reform(Education Commission, HKSAR, 2000, p.25) suggested canceling $20 \%$ of the repeated and outdated curriculum. "The library really will become part of resource-based learning in our school 
instead of an artificially enforced obligation. Classes can be scheduled when the need arises instead of when a "library lesson" was set down." (Fischer, 2000, p.18)

In May 2000, A Pilot Scheme on Collaboration and Learning: Role of the Teacher Librarian, was organized by District Teacher Network, Hong Kong Education Department, under the supervision of James Henri from Australia. During the scheme, three representatives from our school -- the vice principal, the primary one General Studies teacher and me, the teacher librarian at that time, joined a series of workshops. We tried CPT in our school in one topic with one class. The positive feedback from the students encouraged us to try more topics with the same class.

Based on the above guidelines, the feedback and the evaluation from our pilot programs, I suggested a flexible library timetable in the following year to my principal in May 2000, towards the turn of the school year.

\section{Initiated Cooperative Planning and Teaching (CPT) in my school}

"What a school thinks about its resource centre is a measure of what it feels about education." (Fischer, 2000, p.60) After a series of negotiation, I succeeded in getting my principal's approval to change the traditional library timetable into a flexible one since September 2000. As a start, we tried Cooperative Planning and Teaching (CPT) in one subject only -- Chinese Language, in the first term. Then we tried it in English Language in the second term. In the following year, we tried it in Mathematics and General Studies respectively in each of the two school terms. In 2002, we implemented CPT across all subjects. Reading activities were then integrated into all subjects during the Big 6 stages. "Individual students will be able to seek immediate answers to problems which crop up in the classroom. Teachers can share unit activities and resources more effectively and thus save doubling-up on preparation and time." (Fischer, 2000, p.18) I also integrated the Chinese and English Extensive Reading Scheme into the Cooperative Planning and Teaching to start the culture of co-planning among teachers in my school. The library became a learning resource center for teachers and students. Volunteer parents saw students benefit from CPT and were eager to offer help in the library.

\section{References}

Carol-Ann Page. (1999). Developing the School Resource Center Program: A Developing Approach. In Foundations for effective school library media programs, p.226 Chapter 26.

Australian School Library Association \& Australian Library and Information Association. (1993). Learning for the Future. 
Eisenberg \& Berkowitz. (1987). Teaching information \& technology skills: The big 6 in elementary schools. Linworth Publishing, Inc.

Fischer, Judy. (2000). Flexible co-operative library timetabling and what it means, kit 1, cpt kit. Boondall State School

Fischer, Judy. (2000). Resource-based teaching and learning through co-operative planning and teaching, p.60

Henri, James. (1990). Cooperative curriculum planning and team teaching: a conceptual overview. In Cooperative planning and teaching : Australian theory and practice, ed. Henri, James (Occasional Monographs No. 9), Centre for Information Studies, Charles Sturt University, Wagga Wagga, NSW.

The Curriculum Development Council, HKSAR, China. (2001). Learning to Learn - The Way Forward in Curriculum

Education Commission, HKSAR, China. (2000). Consultation Document on Review of Education System: Framework for Education Reform.

Education Commission, HKSAR, China. (2000). Review of Education System: Framework for Education Reform - Education Blue Print for the $21^{\text {st }}$ Century.

Education Department, HKSAR, China. (1997). Report on Review of 9-year Compulsory Education (Revised Version) Chapter 7: Helping Pupils with Learning/Behavioural Problems [available online] http://www.emb.gov.hk/index.aspx?langno=1\&nodeid=557 Accessed on $15^{\text {th }}$ Apr., 2007

Library Section, Advisory Board, Education Department. (1998). Primary Classroom Library Activities: Reference Materials (Chinese)

Wikipedia [available online] http://en.wikipedia.org/wiki/Planet $\quad$ Accessed on $14^{\text {th }}$ Apr., 2007.

\section{Author Note:}

Angel Leung, Committee Member of Hong Kong Teacher Librarians' Association, has shared her experience of CPT in visits to her school and workshops held by the EMB, HK. She has presented sessions in Gui Zhou, Jiangsu, Gansu, Yunnam and Macau in China. She has also been part time teaching Diploma of Teacher Librarianship in HKU SPACE. She is currently East Asia Regional Director for IASL. 